\title{
Erosion of the Himalaya-Karakoram recorded by Indus Fan deposits since the Oligocene
}

\author{
Han Feng ${ }^{1}$, Huayu Lu ${ }^{1 *}$, Barbara Carrapa ${ }^{2}$, Hanzhi Zhang ${ }^{1}$, Jun Chen ${ }^{3}$, Ying Wang ${ }^{1}$ and \\ Peter D. Clift ${ }^{4}$
}

${ }^{1}$ School of Geography and Ocean Science, Nanjing University; Key Laboratory of Coast and Island Development, Ministry of Education, Nanjing 210023, China.

${ }^{2}$ Department of Geosciences, University of Arizona, Tucson, Arizona 85721, USA.

${ }^{3}$ School of Earth Sciences and Engineering, Nanjing University; Key Laboratory of Surficial Geochemistry, Ministry of Education, Nanjing 210023, China.

${ }^{4}$ Department of Geology and Geophysics, Louisiana State University, Baton Rouge, LA 70803, USA.

*Correspondence to: huayulu@nju.edu.cn 


\section{METHODS}

\section{Heavy minerals analysis}

For each bulk sample, the $63-250 \mu \mathrm{m}$ size fraction was extracted using steel sieves. The heavy minerals were separated using sodium polytungstate (density $2.89 \mathrm{~g} / \mathrm{cm}^{3}$ ) with help of funnels (Andò et al., 2020). Following the washing and drying, the fractions of heavy minerals were mounted on glass slides with Canada balsam. For each sample, at least 300 transparent heavy minerals were point-counted under a petrographic microscope at the Laboratory of Earth Surface Process and Environment, Nanjing University, using the method described in Mange and Maurer (1992). Heavy-mineral concentrations index (HMC) were calculated based on Garzanti and Andò (2007).

\section{Zircon U-Pb dating}

More than 200 zircon and apatite grains for each sample were picked from the residual concentrated heavy minerals using a microscope to ensure statistical adequacy (Andersen, 2005). The grains were then mounted in epoxy resin and polished for dating. $\mathrm{U}-\mathrm{Pb}$ isotopes of zircons were measured using an Agilent 7700x ICP-MS with a New Wave $193 \mathrm{~nm}$ laser ablation system at the Laboratory of Earth Surface Process and Environment, Nanjing University. The laser beam diameter was $30 \mu \mathrm{m}$ with a $10 \mathrm{~Hz}$ repetition rate. Zircon 91500 was used as an external standard for isotopic fractionation correction, while NIST 610 (Pearce et al., 1997) was used as the standard for normalizing the unknown $\mathrm{U}$, Th, and $\mathrm{Pb}$ contents. Glitter 4.4 .2 (van Achterbergh et al., 2001) was used to process the raw ICP-MS data. Common Pb was corrected following Andersen (2002). Zircon particle ages were obtained using the following protocol: 1) Individual zircon discordance values $<15 \%$, in agreement with the concordant ages of published data from 
potential sources; 2) ${ }^{206} \mathrm{~Pb} /{ }^{238} \mathrm{U}$ ages were used for zircon grains with ages $<1000 \mathrm{Ma}$ and ${ }^{207} \mathrm{~Pb} /{ }^{206} \mathrm{~Pb}$ ages for older grains. All zircon U-Pb ages and $1 \sigma$ uncertainties are reported in Table DR11.

\section{Apatite Fission Track dating}

Apatite grains were mounted in epoxy on glass slides, polished and etched in 5.5 M nitric acid for $20 \mathrm{~s}$ at $21^{\circ} \mathrm{C}$ (Donelick et al., 2005) before irradiation at Oregon State University. After irradiation, the mica external detectors were etched in $40 \%$ hydrofluoric acid for 15 minutes at $21^{\circ} \mathrm{C}$ (Donelick et al., 2005). Analyses were conducted for optical identification of fission tracks using an Olympus microscope at $1600 \times$ magnification with the drawing tube located above a digitizing tablet and a Kinetek computer-controlled stage driven by the FT Stage program (Dumitru, 1993) at the Fission Track Laboratory of University of Arizona. Apatite fission track ages were calculated using the external detector method (Dumitru, 1993) and are reported in Table DR12.

\section{Nd-Sr isotopic composition}

About $1 \mathrm{~g}$ of the bulk sample was dissolved in $0.5 \mathrm{~mol} / \mathrm{L}$ acetic acid overnight to remove the carbonate component, followed by removal of organic matter using $5 \% \mathrm{H}_{2} \mathrm{O}_{2}$. About $0.1 \mathrm{~g}$ of the sample was used for Nd-Sr isotope analysis. The samples were digested in a mixture of nitric acid and hydrofluoric acid for $36 \mathrm{~h}$ in sealed Teflon vials at $115^{\circ} \mathrm{C}$. The digested solution was then loaded into ion exchange columns to separate $\mathrm{Sr}$ and $\mathrm{Nd}$ elements using $\mathrm{Sr}-\mathrm{Spec}$, Ln-Spec and Tru-Spec resin (Aciego et al., 2009). The determination of $\mathrm{Sr}$ and $\mathrm{Nd}$ isotopes was performed on a Neptune plus Multi-Collector Inductively Coupled Plasma Mass Spectrometer (MC-ICP-MS) at the MOE Key Laboratory of Surficial Geochemistry, Nanjing University. 
Instrumental mass bias for $\mathrm{Sr}$ and $\mathrm{Nd}$ isotopes was corrected by normalizing the ${ }^{86} \mathrm{Sr} /{ }^{88} \mathrm{Sr}$ ratio to 0.1194 and the ${ }^{146} \mathrm{Nd} /{ }^{144} \mathrm{Nd}$ ratio to 0.7219 . Sr standard SRM987 and $\mathrm{Nd}$ standard $\mathrm{JMCNd}_{2} \mathrm{O}_{3}$ were periodically measured to check the reproducibility and accuracy of isotopic analyses, with a mean ${ }^{87} \mathrm{Sr} /{ }^{86} \mathrm{Sr}$ ratio of $0.710239 \pm 42(2 \sigma, \mathrm{n}=10)$ and a mean ${ }^{143} \mathrm{Nd} /{ }^{144} \mathrm{Nd}$ ratio of $0.512099 \pm 15$ $(2 \sigma, n=15)$. A standard material, BCR-2, was used to verify the chemical procedure. Measurements of ten replicates yielded a mean ${ }^{87} \mathrm{Sr} /{ }^{86} \mathrm{Sr}$ value of $0.705018 \pm 20(2 \sigma, \mathrm{n}=10)$ and a mean ${ }^{143} \mathrm{Nd} /{ }^{144} \mathrm{Nd}$ value of $0.512626 \pm 15(2 \sigma, \mathrm{n}=10)$. Epsilon $\mathrm{Nd}$ values $\left(\varepsilon_{\mathrm{Nd}}\right)$ were calculated using chondritic values of ${ }^{143} \mathrm{Nd} /{ }^{144} \mathrm{Nd}=0.512638$ (Jacobsen and Wasserburg, 1980).

\section{Multi-dimensional scaling analysis}

Multi-dimensional scaling (MDS) map is used to illustrate similarities of zircon age distributions of samples (Vermeesch, 2013) in Indus Fan deposits. The dissimilarity or distance between two samples are first defined and calculated based on Kolmogorov-Smirnov test (Feller, 2015):

$$
\delta_{i, j}=\max _{t}\left|F_{i}(t)-F_{j}(t)\right|
$$

Where $F(t)$ is the empirical cumulative distribution function (CDF) of zircon ages.

A matrix of pairwise dissimilarities is shown as:

$$
\delta=\left[\begin{array}{cccc}
\delta_{1,1} & \delta_{1,2} & \cdots & \delta_{1, n} \\
\delta_{2,1} & \delta_{2,2} & \cdots & \delta_{2, n} \\
\vdots & \vdots & \delta_{i, j} & \vdots \\
\delta_{n, 1} & \delta_{n, 2} & \cdots & \delta_{n, n}
\end{array}\right]
$$

Then a monotonically increasing function $\mathrm{f}\left(\delta_{\mathrm{i}, \mathrm{j}}\right)$ and a two-dimensional configuration of points $\mathbf{p}=\left\{\mathrm{p}_{1}, \mathrm{p}_{2}, \ldots, \mathrm{p}_{\mathrm{i}}, \ldots, \mathrm{p}_{\mathrm{j}}, \ldots, \mathrm{p}_{\mathrm{n}}\right\}$ are introduced, with $\mathrm{p}_{\mathrm{i}}=\left(\mathrm{x}^{\mathrm{i}}, \mathrm{y}^{\mathrm{i}}\right), \mathrm{p}_{\mathrm{j}}=\left(\mathrm{x}^{\mathrm{j}}, \mathrm{y}^{\mathrm{j}}\right)$ and $1 \leq \mathrm{i}, \mathrm{j} \leq \mathrm{n}$. The Euclidean distance between any two points $\mathrm{p}_{\mathrm{i}}$ and $\mathrm{p}_{\mathrm{j}}$ in this configuration should be approximated 
to the $\mathrm{f}\left(\delta_{\mathrm{i}, \mathrm{j}}\right)$. According to this, configuration $\mathbf{p}$ can be found analytically by relatively straightforward linear algebra (Cox and Cox, 2008), and plotted on a MDS map (Fig. DR1).

\section{References}

Aciego, S.M., Bourdon, B., Lupker, M., and Rickli, J., 2009, A new procedure for separating and measuring radiogenic isotopes (U, Th, $\mathrm{Pa}, \mathrm{Ra}, \mathrm{Sr}, \mathrm{Nd}, \mathrm{Hf})$ in ice cores: Chemical Geology, v. 266, no. 3-4, p. 194-204, doi: 10.1016/j.chemgeo.2009.06.003.

Andersen, T., 2002, Correction of common lead in U-Pb analyses that do not report $204 \mathrm{~Pb}$ : Chemical Geology, v. 192, no. 1-2, p. 59-79, doi: 10.1016/S0009-2541(02)00195-X.

Andersen, T., 2005, Detrital zircons as tracers of sedimentary provenance: limiting conditions from statistics and numerical simulation: Chemical Geology, v. 216, no. 3-4, p. 249-270, doi: 10.1016/j.chemgeo.2004.11.013.

Andò, S., 2020, Gravimetric Separation of Heavy Minerals in Sediments and Rocks: Minerals, v. 10, no. 3, p. 273-15, doi: 10.3390/min10030273.

Cox, M.A.A., and Cox, T.F., 2008, Multidimensional Scaling, in Handbook of Data Visualization, Springer Berlin Heidelberg, Berlin, Heidelberg, p. 315-347.

Donelick, R.A., O'Sullivan, P.B., and Ketcham, R.A., 2005, Apatite Fission-Track Analysis: Reviews in Mineralogy and Geochemistry, v. 58, no. 1, p. 49-94, doi: 10.2138/rmg.2005.58.3.

Dumitru, T.A., 1993, A new computer-automated microscope stage system for fission-track analysis: Nuclear Tracks and Radiation Measurements, v. 21, no. 4, p. 575-580, doi: 10.1016/1359-0189(93)90198-I.

Feller, W., 2015, On the Kolmogorov-Smirnov Limit Theorems for Empirical Distributions, in Selected Papers I, Springer International Publishing, Cham, p. 735-749. 
Garzanti, E., and Andò, S., 2007, Heavy Mineral Concentration in Modern Sands: Implications for Provenance Interpretation, in Heavy Minerals in Use, Developments in Sedimentology, Elsevier, p. 517-545.

Jacobsen, S.B., and Wasserburg, G.J., 1980, Sm-Nd isotopic evolution of chondrites: Earth and Planetary Science Letters, v. 50, no. 1, p. 139-155, doi: 10.1016/0012-821X(80)90125-9.

Mange, M.A., and Maurer, H.F.W., 1992, Heavy Minerals in Colour: Springer, Dordrecht.

Pearce, N.J.G., Perkins, W.T., Westgate, J.A., Gorton, M.P., Jackson, S.E., Neal, C.R., and Chenery, S.P., 1997, A Compilation of New and Published Major and Trace Element Data for NIST SRM 610 and NIST SRM 612 Glass Reference Materials: Geostandards Newsletter, v. 21, p. 115-144, doi: 10.1111/j.1751-908X.1997.tb00538.x.

Van Achterbergh, E., Ryan, C.G., Jackson, S.E., and Griffin, W.L., 2001, Data reduction software for LA-ICP-MS, in Sylvester, P.J. ed., Laser-ablation-ICPMS in the earth sciences: Principles and applications (Short course series), Ottawa, p. 239-243.

Vermeesch, P., 2013, Multi-sample comparison of detrital age distributions: Chemical Geology, v. 341, p. 140-146, doi: 10.1016/j.chemgeo.2013.01.010. 


\section{AGE CONTROL}

The chronology of Sites 722 and 731 was established based on the Initial Reports for ODP Sites 722 and 731 (Shipboard Scientific Party, 1989a, 1989b; Prell and Niitsuma, 1989). The upper parts of Sites 722 and $731(<\sim 15 \mathrm{Ma})$ have adequate fossil assemblages and paleomagnetic data, as indicated in the Initial Report (Fig. 1D and Table DR1) (Prell and Niitsuma, 1989). The lower parts $(>\sim 15 \mathrm{Ma})$ of Sites 722 and 731 have few fossil assemblage data and no paleomagnetic data, and thus there is no age control proposed in Prell and Niitsuma (1989). We first updated the reported age controls of the upper parts of Sites 722 and 731 according to Gradstein (2012), and then, estimated the age controls in the lower part based on the nannofossil assemblage events that were reported by Shipboard Scientific Party, 1989a, 1989b.

For Site 722, the deepest age control point reported in the Initial Report was $13.8 \mathrm{Ma}$, which was obtained from the 'T Globorotalia peripheronda' faunal event (here, ' $\mathrm{T}$ ' denotes 'Top limit') at the depth of 391.80-393.86 mbsf (meters below the sea floor). Below this depth, the Initial Report indicate that the sediments at $565.6 \mathrm{mbsf}$ contained the nannofossil species Sphenolithus belemnos (17.95-19.03 Ma) and Discoaster druggi (17.95-22.82 Ma). Here we use the average of 18.49 Ma for the age range of Sphenolithus belemnos (17.95-19.03 Ma) as the age control for a depth of $565.6 \mathrm{mbsf}$ at Site 722 . In the same way, the age controls for Site 731 below the lowest reported 'T Sphenolithus heteromorphus' faunal event of 13.53 Ma at depths of 299.2-300.35 were obtained according to the Initial Report. Sediments at depths of $371.1 \mathrm{mbsf}$ and 514.4 mbsf both contained Sphenolithus belemnos and are thus likely to be within the age range of Sphenolithus belemnos (17.95-19.03 Ma). The sediments at the depth of $629.3 \mathrm{mbsf}$ contained Cyclicargolithus abisectus (>24.67 Ma) and Dictyococcites bisectus (23.13-38.25 Ma), indicating ages older than $24 \mathrm{Ma}$. We obtained $24.67 \mathrm{Ma}$ as the age at a depth of $629.3 \mathrm{mbsf}$. 
The nannofossil assemblage at a depth of 807.85 mbsf includes Cyclicargolithus abisectus ( $>24.67 \mathrm{Ma})$, Cyclicargolithus floridanus (>11.85 Ma), Discoaster deflandrei ( $>15.8 \mathrm{Ma})$, Helicosphaera euphratis (14.91-37.32 Ma), Helicosphaera recta (22.82-32.92 Ma), and Sphenolithus ciperoensis (24.43-29.62 Ma). As $807.85 \mathrm{mbsf}$ is much deeper than $629.3 \mathrm{mbsf}$ and the age of $807.85 \mathrm{mbsf}$ cannot be younger than that of $629.3 \mathrm{mbsf}$, we took the average rather than the upper limit age of the time range of Sphenolithus ciperoensis (24.43-29.62 Ma), which yields the age of $27.03 \mathrm{Ma}$ for the depth of $807.85 \mathrm{mbsf}$. We then linearly interpolated and extrapolated ages for each sampling depth both between and beyond the estimated age controls (Fig. 1D).

However, the age controls for sediments older than $\sim 24 \mathrm{Ma}$ are extrapolated, because none of the reported nannofossil assemblage in the lower part of the sites has a Last Appearance Datum (LAD) older than 24.43 or $24.67 \mathrm{Ma}$. Therefore, the age range of strata investigated by this study can be considered as $>24-16 \mathrm{Ma}$.

\section{DECOMPACTION}

Decompaction is a technique that restores present-day thicknesses to sedimentary layers during the burial history by use of porosity-depth relationships (Sclater and Christie, 1980; Allen and Allen, 2013). The widely used porosity-depth relation has the form of a negative exponential as:

$$
\varphi(\mathrm{y})=\varphi_{0} e^{-c y}
$$

where $\varphi_{0}$ is the porosity at the surface, $\mathrm{y}$ is the depth and $\mathrm{c}$ is a coefficient determining the slope of the $\phi$-depth curve. The porosity data with depth of ODP site 722 and 731 can be found in the Initial Report for ODP Sites 722 and 731 (Prell and Niitsuma, 1989). We obtained $\varphi_{0}=$ $73 \%$ and $\mathrm{c}=0.001$ for the site 722 and $\varphi_{0}=64 \%$ and $\mathrm{c}=0.0008$ for Site 731 (Fig. DR2). 
Consider a sediment layer at present burial depths of $y_{1}$ and $y_{2}$ that is to be restored to new shallower depths $\mathrm{y}_{1}{ }^{\prime}$ and $\mathrm{y}_{2}{ }^{\prime}$. The volume of water-filled pore space $\mathrm{V}_{\mathrm{w}}$ between depths $\mathrm{y}_{1}$ and $\mathrm{y}_{2}$ is simply the porosity integrated over the depth interval:

$$
V_{w}=\int_{y_{1}}^{y_{2}} \varphi_{0} e^{-c y} \mathrm{~d} y
$$

which on integration gives:

$$
V_{w}=\frac{\varphi_{0}}{c}\left(e^{-c y_{1}}-e^{-c y_{2}}\right)
$$

The total volume of the sediment layer $\left(\mathrm{V}_{\mathrm{t}}\right)$ is the volume due to pore-filling water $\left(\mathrm{V}_{\mathrm{w}}\right)$ and the volume of the sediment grains $\left(\mathrm{V}_{\mathrm{s}}\right)$ :

$$
V_{s}=V_{t}-V_{w}
$$

Considering a unit cross-sectional area:

$$
y_{s}=y_{t}-y_{w}=\left(y_{2}-y_{1}\right)-\frac{\varphi_{0}}{c}\left(e^{-c y_{1}}-e^{-c y_{2}}\right)
$$

And the same for the shallower layer $\mathrm{y}_{1}{ }^{\prime}$ and $\mathrm{y}_{2}{ }^{\prime}$ :

$$
y_{s}{ }^{\prime}=y_{t}{ }^{\prime}-y_{w}{ }^{\prime}=\left(y_{2}{ }^{\prime}-y_{1}{ }^{\prime}\right)-\frac{\varphi_{0}}{c}\left(e^{-c y_{1}{ }^{\prime}}-e^{-c y_{2}{ }^{\prime}}\right)
$$

Since the volume of the sediment grains remain the same during the decompaction $\left(y_{s}=y_{s}{ }^{\prime}\right)$, thus the restored thickness is:

$$
y_{2}^{\prime}-y_{1}^{\prime}=\left(y_{2}-y_{1}\right)-\frac{\varphi_{0}}{c}\left(e^{-c y_{1}}-e^{-c y_{2}}\right)+\frac{\varphi_{0}}{c}\left(e^{-c y_{1^{\prime}}}-e^{-c y_{2}}\right)
$$

We restored every $1 \mathrm{~m}$ of the sedimentary layer of the ODP Site 722 and 731 to the surface and obtained the restored depth for every samples and age controls (Table DR2).

\section{References}

Allen, P.A., and Allen, J.R., 2013, Basin Analysis: Principles and Application to Petroleum Play 
Assessment: Oxford.

Gradstein, F.M., 2012, Biochronology, in Gradstein, F.M., Ogg, J.G., Schmitz, M.D., and Ogg, G.M. eds., The Geologic Time Scale, Elsevier, Amsterdam, p. 43-61.

Prell, W.L., and Niitsuma, N., 1989, Proceedings of the Ocean Drilling Program, Initial Reports, 117: Ocean Drilling Program, College Station, TX.

Sclater, J.G., and Christie, P.A.F., 1980, Continental stretching: An explanation of the Post-Mid-Cretaceous subsidence of the central North Sea Basin: Journal of Geophysical Research: Solid Earth, v. 85, no. B7, p. 3711-3739, doi: 10.1029/JB085iB07p03711.

Shipboard Scientific Party, 1989a. Site 722. In: Prell, W.L., Niitsuma, N. (Eds.), Proceedings of the Ocean Drilling Program, Part A: Initial Reports, 17, Ocean Drilling Program, College Station, TX, pp. 255-317,

Shipboard Scientific Party, 1989b. Site 731. In: Prell, W.L., Niitsuma, N. (Eds.), Proc. ODP, Initial Reports, 117, Ocean Drilling Program, College Station, TX, pp. 585-652, doi:10.2973/odp.proc.ir.117.108.1989. 


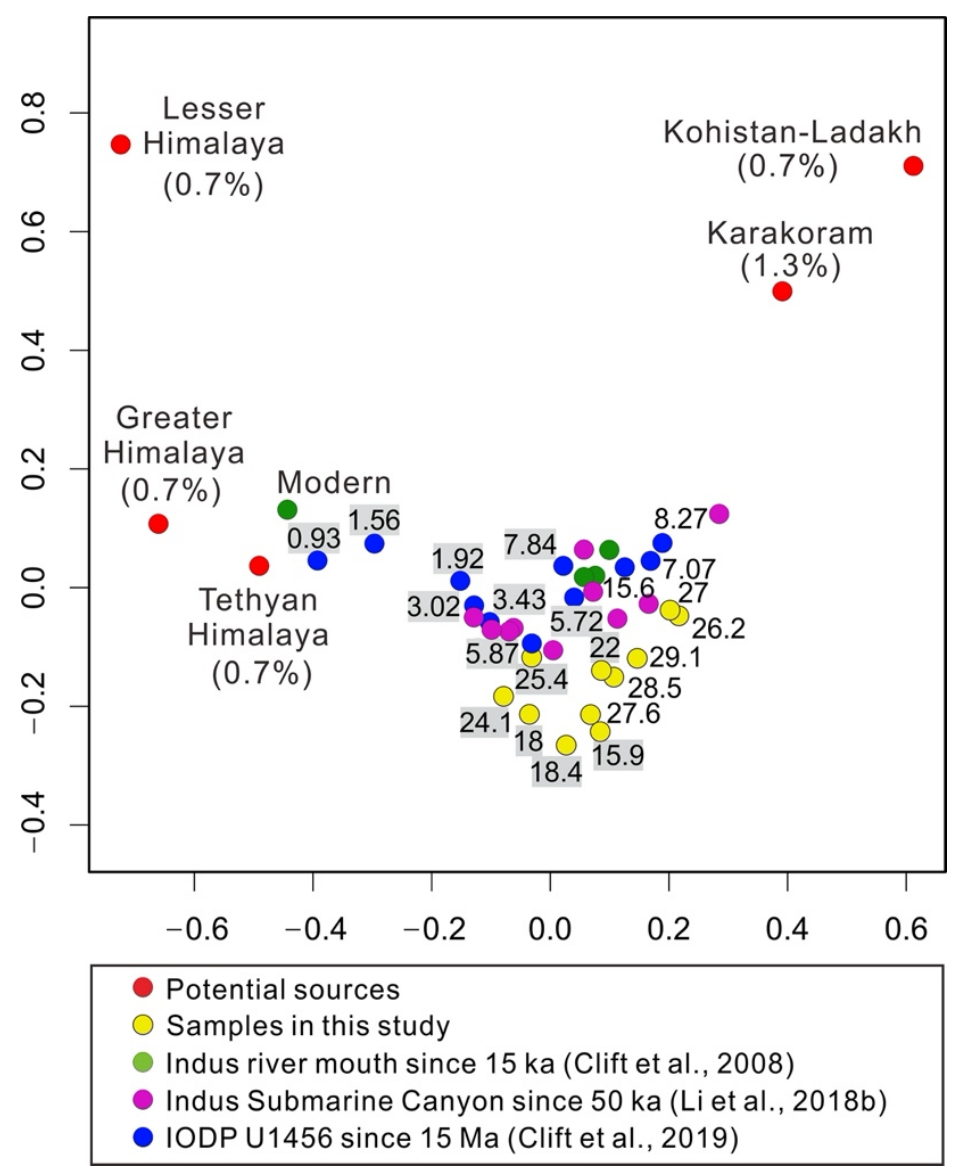

Fig. DR1. Multi-dimensional scalar (MDS) diagram of zircon U-Pb age distributions from Indus Fan deposits dated by this study and previous studies, compared with the potential sources. Concentrations of zircon grains in heavy mineral suits of the sources are labeled as percentage with parentheses (Table DR7); The samples from this study and from IODP Site U1456 were labeled with their depositional ages (Ma). The labels of samples dated at 25-16 Ma and $<6$ Ma have grey backgrounds, all of which are closer to the Himalayan sources than the others. 

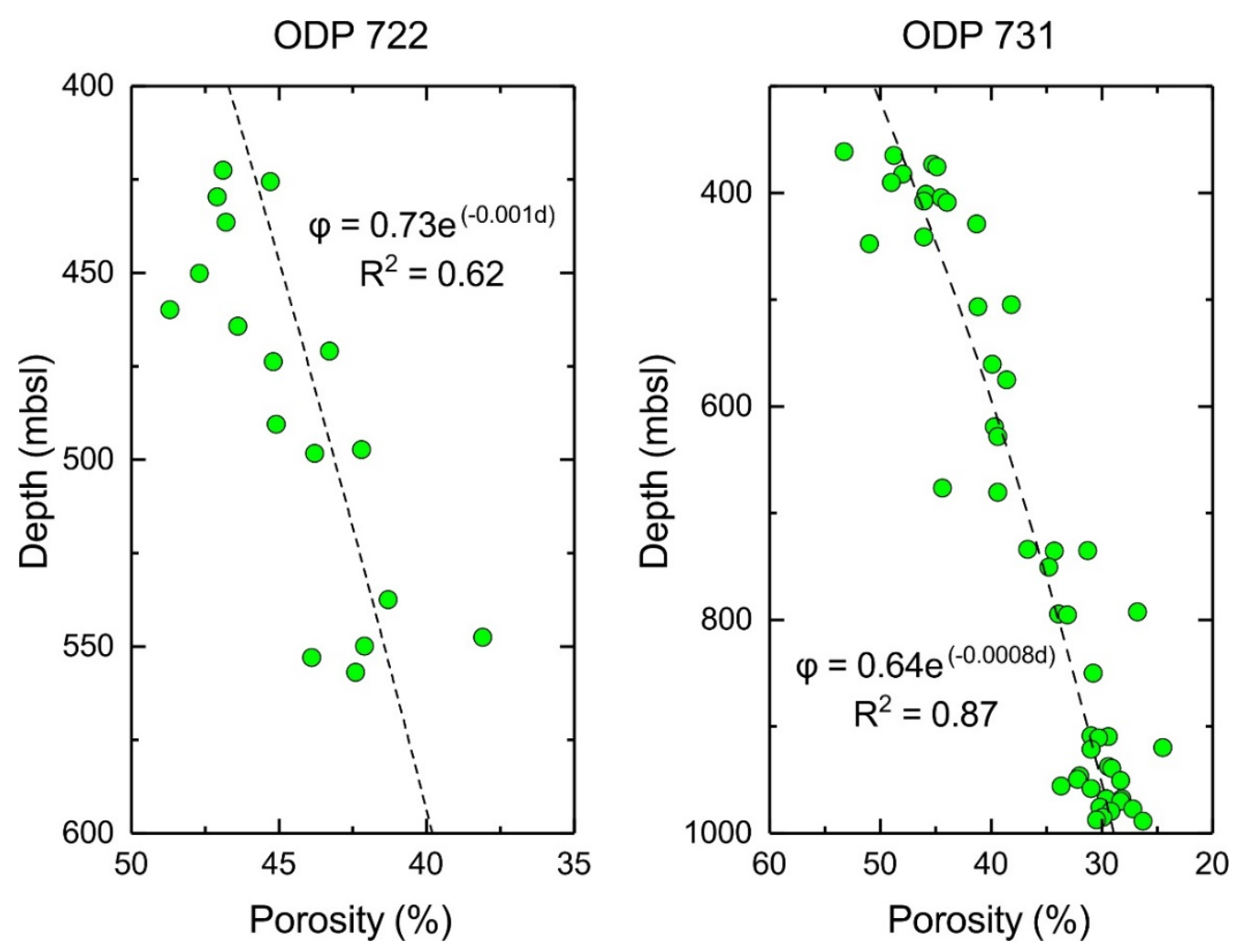

Fig. DR2. Porosity-depth relationship of ODP Sites 722 and 731 for sediments $<400$ mbsl. Porosity data are from Prell and Niitsuma (1989). 


\section{Table DR1.}

Biostratigraphic and magnetostratigraphic age controls for ODP Sites 722 and 731

\begin{tabular}{|c|c|c|}
\hline $\begin{array}{l}\text { Depth below the } \\
\text { seafloor (mbsl) }\end{array}$ & Event & Age $(\mathrm{Ma})$ \\
\hline \multicolumn{3}{|c|}{ ODP Site 722} \\
\hline 5.65 & $B^{*}$ Emiliania huxleyi & 0.29 \\
\hline 16.95 & T Pseudoemiliania lacunosa & 0.44 \\
\hline 24.75 & B Pterocorys hertwegii & 0.74 \\
\hline 31.68 & Tc Reticulofenestra asanoi & 0.91 \\
\hline 37.65 & B Jaramillo & 1.07 \\
\hline 53.85 & B Gephyrocapsa spp. $>4 \mu \mathrm{m}$ & 1.73 \\
\hline 63.14 & T Discoaster brouweri & 1.93 \\
\hline 74.35 & T Discoaster pentaradiatus & 2.39 \\
\hline 82.45 & Matuyama/Gauss & 2.58 \\
\hline 101.55 & T Phormostichoartus fistula & 3.49 \\
\hline 115.6 & T Spongaster pentas; B Spongaster tetras tetras & 4.13 \\
\hline 134.9 & T Didymocyrtis penultima; B Didymocyrtis avita & 4.24 \\
\hline 142.03 & T Sidufjall & 4.80 \\
\hline 151 & B Thvera & 5.24 \\
\hline 163.9 & T Discoaster quinqueramus & 5.59 \\
\hline 178.95 & B Pterocorys campanula; T Siphostichartus corona & 5.67 \\
\hline 188.45 & B Pulleniatina primalis & 6.60 \\
\hline 208.05 & T Acrobotrys tritubus & 6.34 \\
\hline 227.35 & T Calocycletta caepa & 6.14 \\
\hline 241.7 & B Solenosphaera omnitubus omnitubus & 7.41 \\
\hline 275.6 & T Diartus petterssoni; B Diartus hughesi & 8.84 \\
\hline 287.45 & B Neogloboquadrina acostaensis & 9.83 \\
\hline 304.7 & T Discoaster hamatus & 9.53 \\
\hline 329.35 & T Cyrtocapsella japonica & 9.86 \\
\hline
\end{tabular}




\begin{tabular}{|c|c|c|}
\hline 339.05 & B Globoturborotalita nepenthes & 11.63 \\
\hline 358.25 & T Fohsella fohsi; Fohsella plexus & 11.79 \\
\hline 375.1 & Bc Discoaster kugleri & 11.90 \\
\hline 382.41 & T Sphenolithus heteromorphus & 13.53 \\
\hline 391.8 & T Fohsella peripheroronda & 13.80 \\
\hline 565.6 & Sphenolithus belemnos and Discoaster druggi & 18.49 \\
\hline \multicolumn{3}{|c|}{ ODP Site 731} \\
\hline 5.62 & B Emiliania huxleyi & 0.29 \\
\hline 18.45 & T Pseudoemiliania lacunosa & 0.44 \\
\hline 24.65 & T Anthocyrtidium nosicaae & 0.70 \\
\hline 34.15 & B Pterocorys hertwegii & 0.74 \\
\hline 45.45 & B Jaramillo & 1.07 \\
\hline 56.45 & T Helicosphaera sellii & 1.26 \\
\hline 64.45 & T Calcidiscus macintyrei & 1.60 \\
\hline 72.35 & T Pterocanium prismatium; Theocorythium ventulum & 2.04 \\
\hline 83.85 & T Discoaster brouweri & 1.93 \\
\hline 96 & T Discoaster pentaradiatus & 2.39 \\
\hline 105.7 & T Spongaster pentas; B Spongaster tetras tetras & 4.13 \\
\hline 115.4 & B Stichocorys delmontensis; T Stichocorys peregrina & 7.78 \\
\hline 130.35 & B Solenosphaera omnitubus omnitubus & 7.41 \\
\hline 140.95 & T Diartus petterssoni; B Diartus hughesi & 8.84 \\
\hline 149.75 & T Dictyocoryne ontongensis & 7.94 \\
\hline 163.7 & B Discoaster quinqueramus & 8.12 \\
\hline 178.75 & $\begin{array}{l}\text { T Didymocyrtis laticonus; B Didymocyrtis } \\
\text { antepenultima }\end{array}$ & 8.84 \\
\hline 192.8 & B Spongaster berminghami & 8.35 \\
\hline 202.5 & T Discoaster hamatus & 9.53 \\
\hline 227.25 & T Cyrtocapsella japonica & 9.86 \\
\hline 238.75 & B Discoaster hamatus & 10.55 \\
\hline 299.2 & T Sphenolithus heteromorphus & 13.53 \\
\hline
\end{tabular}


371.1 T Sphenolithus belemnos $\quad 17.95$

$\begin{array}{lll}514.4 & B \text { Sphenolithus belemnos } & 19.03\end{array}$

$\begin{array}{lll}629.3 & \text { TCyclicargolithus abisectus } & 24.67\end{array}$

$807.85 \quad$ Sphenolithus ciperoensis 27.03

${ }^{*} \mathrm{~T}=$ top, $\mathrm{Tc}=$ top common, $\mathrm{B}=$ bottom, $\mathrm{Bc}=$ bottom common 
Table DR2.

Sample details including restored depth, interpolated ages and analytical methods

\begin{tabular}{|c|c|c|c|c|c|c|c|}
\hline Sample name & Depth (mbsl) & $\begin{array}{c}\text { Restored } \\
\text { depth } \\
(\mathrm{mbs})\end{array}$ & Age (Ma) & $\begin{array}{c}\text { Apatite } \\
\text { Fission } \\
\text { track } \\
\text { dating }\end{array}$ & $\begin{array}{c}\text { Zircon } \\
\mathrm{U}-\mathrm{Pb} \\
\text { dating }\end{array}$ & $\begin{array}{l}\text { Heavy } \\
\text { mineral } \\
\text { analysis }\end{array}$ & $\begin{array}{l}\mathrm{Nd}-\mathrm{Sr} \\
\text { isotope }\end{array}$ \\
\hline 722B-50X-1W & 470.2 & 734.4 & 15.8 & $\sqrt{ }$ & $\sqrt{ }$ & $\sqrt{ }$ & $\sqrt{ }$ \\
\hline 722B-50X-4W & 473.6 & 742.6 & 15.9 & & & & $\sqrt{ }$ \\
\hline 722B-57X-1W & 537.2 & 875.1 & 17.6 & & & & $\sqrt{ }$ \\
\hline 722B-58X-1W & 547.1 & 896.7 & 17.9 & & & & $\sqrt{ }$ \\
\hline $731 \mathrm{~A}-41 \mathrm{X}-3 \mathrm{~W}$ & 383.6 & 479.8 & 18.0 & & $\sqrt{ }$ & $\sqrt{ }$ & \\
\hline $731 \mathrm{~A}-42 \mathrm{X}-1 \mathrm{~W}$ & 390.8 & 490.2 & 18.1 & & & & $\sqrt{ }$ \\
\hline $731 \mathrm{~B}-3 \mathrm{X}-1 \mathrm{~W}$ & 428.3 & 545.8 & 18.4 & & & & $\sqrt{ }$ \\
\hline $731 \mathrm{~B}-4 \mathrm{X}-1 \mathrm{~W}$ & 428.9 & 547.3 & 18.4 & $\sqrt{ }$ & $\sqrt{ }$ & $\sqrt{ }$ & \\
\hline $731 \mathrm{C}-2 \mathrm{R}-1 \mathrm{~W}$ & 503.1 & 662.7 & 18.9 & & & & $\sqrt{ }$ \\
\hline $731 \mathrm{C}-2 \mathrm{R}-2 \mathrm{~W}$ & 504.9 & 665.9 & 19.0 & & & & $\sqrt{ }$ \\
\hline 731C-4R-1W & 561.2 & 756.8 & 21.3 & & & & $\sqrt{ }$ \\
\hline $731 \mathrm{C}-5 \mathrm{~W}-4 \mathrm{~W}$ & 575.7 & 781.7 & 22.0 & $\sqrt{ }$ & $\sqrt{ }$ & $\sqrt{ }$ & $\sqrt{ }$ \\
\hline 731C-6R-1W & 618.1 & 852.3 & 24.1 & & $\sqrt{ }$ & & $\sqrt{ }$ \\
\hline $731 \mathrm{C}-7 \mathrm{~W}-3 \mathrm{~W}$ & 631.6 & 876.3 & 24.7 & & & & $\sqrt{ }$ \\
\hline $731 \mathrm{C}-8 \mathrm{R}-4 \mathrm{~W}$ & 681.3 & 961.2 & 25.3 & $\sqrt{ }$ & $\sqrt{ }$ & $\sqrt{ }$ & $\sqrt{ }$ \\
\hline $731 \mathrm{C}-9 \mathrm{~W}-6 \mathrm{~W}$ & 693.1 & 982.4 & 25.5 & & & & $\sqrt{ }$ \\
\hline $731 \mathrm{C}-11 \mathrm{~W}-1 \mathrm{~W}$ & 745.5 & 1077.1 & 26.2 & & $\sqrt{ }$ & $\sqrt{ }$ & $\sqrt{ }$ \\
\hline $731 \mathrm{C}-13 \mathrm{~W}-4 \mathrm{~W}$ & 806.8 & 1188.9 & 27.0 & $\sqrt{ }$ & $\sqrt{ }$ & $\sqrt{ }$ & $\sqrt{ }$ \\
\hline 731C-14R-2W & 850.7 & 1271.2 & 27.6 & & $\sqrt{ }$ & $\sqrt{ }$ & $\sqrt{ }$ \\
\hline 731C-17R-2W & 918.1 & 1399.3 & 28.6 & & $\sqrt{ }$ & $\sqrt{ }$ & $\sqrt{ }$ \\
\hline 731C-22R-1W & 965.9 & 1495.0 & 29.3 & $\sqrt{ }$ & $\sqrt{ }$ & $\sqrt{ }$ & $\sqrt{ }$ \\
\hline
\end{tabular}




\section{Table DR3.}

Detrital heavy mineral assemblages of the orogenic belts in sediment provenance in the Indus River drainage basin (Liang et al., 2019)

\begin{tabular}{ccccccccccc}
\hline $\begin{array}{c}\text { Tectonic } \\
\text { Units }\end{array}$ & HMC $^{*}$ & Ap and Ttn & Spinel & Px & Am & Grt & HgM & Ep & ZTR & Total \\
\hline Karakoram & 5.7 & 14 & 0 & 8 & 43 & 10 & 1 & 18 & 6 & 100 \\
Ladakh & 11.1 & 8 & 0 & 6 & 78 & 1 & 0 & 5 & 2 & 100 \\
Kohistan & 37.8 & 5 & 0 & 23 & 50 & 1 & 0 & 20 & 1 & 100 \\
Himalaya & 4.8 & 12 & 0 & 13 & 27 & 22 & 10 & 7 & 9 & 100 \\
\hline
\end{tabular}

${ }^{*} \mathrm{HMC}=$ Heavy mineral concentration; $\mathrm{Ap}=$ apatite; $\mathrm{Ttn}=$ titanite; $\mathrm{Px}=$ pyroxene; $\mathrm{Am}=$ amphibole; Grt = garnet; $\mathrm{HgM}$ = high-grade minerals (staurolite, andalusite, kyanite, sillimanite); Ep = epidote; ZTR = ultrastable minerals (zircon, tourmaline, rutile) 
Table DR4.

$\mathrm{Nd}-\mathrm{Sr}$ isotopic composition of samples from ODP Sites 722 and 731

\begin{tabular}{|c|c|c|c|c|c|c|}
\hline Sample name & Age (Ma) & ${ }^{143} \mathrm{Nd} /{ }^{144} \mathrm{Nd}$ & $\mathrm{SE}$ & $\varepsilon_{\mathrm{Nd}}{ }^{*}$ & ${ }^{87} \mathrm{Sr} /{ }^{86} \mathrm{Sr}$ & $\mathrm{SE}$ \\
\hline 722B-50X-1W & 15.8 & 0.512053 & 5 & -11.42 & 0.723999 & 7 \\
\hline 722B-50X-4W & 15.9 & 0.512034 & 11 & -11.77 & 0.727225 & 8 \\
\hline 722B-57X-1W & 17.6 & 0.512075 & 7 & -10.99 & 0.725464 & 7 \\
\hline 722B-58X-1W & 17.9 & 0.512010 & 8 & -12.25 & 0.722252 & 8 \\
\hline 731A-42X-1W & 18.1 & 0.512029 & 5 & -11.87 & 0.723988 & 7 \\
\hline $731 \mathrm{~B}-3 \mathrm{X}-1 \mathrm{~W}$ & 18.4 & 0.512035 & 6 & -11.77 & 0.717237 & 8 \\
\hline $731 \mathrm{C}-2 \mathrm{R}-1 \mathrm{~W}$ & 18.9 & 0.512071 & 10 & -11.06 & 0.724488 & 8 \\
\hline $731 \mathrm{C}-2 \mathrm{R}-2 \mathrm{~W}$ & 19.0 & 0.512028 & 5 & -11.91 & 0.724971 & 8 \\
\hline $731 \mathrm{C}-4 \mathrm{R}-1 \mathrm{~W}$ & 21.3 & 0.512005 & 6 & -12.35 & 0.732802 & 7 \\
\hline $731 C-5 W-4 W$ & 22.0 & 0.512004 & 5 & -12.36 & 0.725374 & 7 \\
\hline $731 \mathrm{C}-6 \mathrm{R}-1 \mathrm{~W}$ & 24.1 & 0.512032 & 7 & -11.82 & 0.729545 & 7 \\
\hline $731 \mathrm{C}-7 \mathrm{~W}-3 \mathrm{~W}$ & 24.7 & 0.512081 & 10 & -10.87 & 0.729158 & 8 \\
\hline 731C-8R-4W & 25.3 & 0.512019 & 7 & -12.08 & 0.725372 & 9 \\
\hline $731 \mathrm{C}-9 \mathrm{~W}-6 \mathrm{~W}$ & 25.5 & 0.512048 & 7 & -11.51 & 0.721798 & 7 \\
\hline $731 \mathrm{C}-11 \mathrm{~W}-1 \mathrm{~W}$ & 26.2 & 0.512016 & 7 & -12.13 & 0.723202 & 6 \\
\hline $731 \mathrm{C}-13 \mathrm{~W}-4 \mathrm{~W}$ & 27.0 & 0.512005 & 6 & -12.35 & 0.722325 & 7 \\
\hline 731C-14R-2W & 27.6 & 0.512015 & 6 & -12.15 & 0.723071 & 9 \\
\hline 731C-17R-2W & 28.6 & 0.511993 & 8 & -12.58 & 0.721050 & 7 \\
\hline 731C-22R-1W & 29.3 & 0.511980 & 8 & -12.84 & 0.724034 & 7 \\
\hline
\end{tabular}

${ }^{*} \varepsilon_{\mathrm{Nd}}$ values are expressed relative to chondrite values of ${ }^{143} \mathrm{Nd} /{ }^{144} \mathrm{Nd}=0.512638: \varepsilon_{\mathrm{Nd}}=$ $\left({ }^{143} \mathrm{Nd} /{ }^{144} \mathrm{Nd}-0.512638\right) / 0.512638 \times 1000$ 


\section{Table DR5.}

Detrital heavy mineral assemblages of samples from ODP Sites 722 and 731

\begin{tabular}{cccccccccccc}
\hline Sample name & $\begin{array}{c}\text { Age } \\
\text { (Ma) }\end{array}$ & HMC $^{*}$ & Ap and Ttn & Spinel & Px & Am & Grt & HgM & Ep & ZTR & Total \\
\hline 722B-50X-1W & 15.8 & 5.5 & 5 & 4 & 1 & 66 & 10 & 4 & 2 & 8 & 100 \\
731A-41X-3W & 18.0 & 4.7 & 3 & 4 & 0 & 43 & 6 & 5 & 25 & 14 & 100 \\
$731 \mathrm{~B}-4 \mathrm{X}-1 \mathrm{~W}$ & 18.4 & 5.4 & 5 & 3 & 2 & 33 & 25 & 4 & 19 & 8 & 100 \\
$731 \mathrm{C}-5 \mathrm{~W}-4 \mathrm{~W}$ & 22.0 & 4.8 & 1 & 0 & 0 & 58 & 22 & 6 & 10 & 3 & 100 \\
$731 \mathrm{C}-8 \mathrm{R}-4 \mathrm{~W}$ & 25.3 & 2.8 & 10 & 0 & 22 & 7 & 10 & 12 & 23 & 16 & 100 \\
$731 \mathrm{C}-11 \mathrm{~W}-1 \mathrm{~W}$ & 26.2 & 1.1 & 7 & 0 & 13 & 9 & 14 & 9 & 32 & 16 & 100 \\
$731 \mathrm{C}-13 \mathrm{~W}-4 \mathrm{~W}$ & 27.0 & 1.8 & 12 & 0 & 14 & 4 & 10 & 5 & 41 & 14 & 100 \\
$731 \mathrm{C}-14 \mathrm{R}-2 \mathrm{~W}$ & 27.6 & 2.3 & 8 & 19 & 0 & 0 & 36 & 0 & 12 & 26 & 100 \\
$731 \mathrm{C}-17 \mathrm{R}-2 \mathrm{~W}$ & 28.6 & 1.0 & 5 & 7 & 0 & 0 & 27 & 5 & 8 & 48 & 100 \\
$731 \mathrm{C}-22 \mathrm{R}-1 \mathrm{~W}$ & 29.3 & 1.3 & 24 & 4 & 0 & 0 & 15 & 0 & 11 & 45 & 100 \\
\hline
\end{tabular}

${ }^{*} \mathrm{HMC}=$ Heavy mineral concentration; $\mathrm{Ap}=$ apatite $; \mathrm{Ttn}=$ titanite Px = pyroxene; $\mathrm{Am}=$ amphibole; Grt = garnet; HgM = high-grade minerals (staurolite, andalusite, kyanite, sillimanite); Ep = epidote; ZTR = ultrastable minerals (zircon, tourmaline, rutile) 


\section{Table DR6}

Estimations of zircon particles from potential sediment sources to the samples from ODP Sites 722 and 731

\begin{tabular}{|c|c|c|c|c|c|c|c|c|}
\hline \multirow{2}{*}{ Sample name } & \multirow{2}{*}{$\begin{array}{l}\text { Age } \\
\text { (Ma) }\end{array}$} & \multicolumn{3}{|c|}{ Zircon grains } & \multicolumn{2}{|c|}{ Zircon budget* } & \multicolumn{2}{|c|}{ Bulk budget ${ }^{\dagger}$} \\
\hline & & $\begin{array}{c}<200 \\
\mathrm{Ma}\end{array}$ & $\begin{array}{c}>200 \\
\mathrm{Ma}\end{array}$ & Total & EAP & Himalaya & EAP & Himalaya \\
\hline 722B-50X-1W & 15.8 & 19 & 94 & 113 & $17 \%$ & $83 \%$ & $12 \%$ & $88 \%$ \\
\hline 731A-41X-3W & 18.0 & 24 & 107 & 131 & $18 \%$ & $82 \%$ & $14 \%$ & $86 \%$ \\
\hline 731B-4X-1W & 18.4 & 17 & 124 & 141 & $12 \%$ & $88 \%$ & $9 \%$ & $91 \%$ \\
\hline 731C-5W-4W & 22.0 & 37 & 112 & 149 & $25 \%$ & $75 \%$ & $19 \%$ & $81 \%$ \\
\hline 731C-6R-1W & 24.1 & 23 & 121 & 144 & $16 \%$ & $84 \%$ & $12 \%$ & $88 \%$ \\
\hline 731C-8R-4W & 25.3 & 34 & 103 & 137 & $25 \%$ & $75 \%$ & $19 \%$ & $81 \%$ \\
\hline $731 \mathrm{C}-11 \mathrm{~W}-1 \mathrm{~W}$ & 26.2 & 64 & 81 & 145 & $44 \%$ & $56 \%$ & $36 \%$ & $64 \%$ \\
\hline $731 \mathrm{C}-13 \mathrm{~W}-4 \mathrm{~W}$ & 27.0 & 63 & 91 & 154 & $41 \%$ & $59 \%$ & $33 \%$ & $67 \%$ \\
\hline 731C-14R-2W & 27.6 & 24 & 102 & 126 & $19 \%$ & $81 \%$ & $14 \%$ & $86 \%$ \\
\hline 731C-17R-2W & 28.6 & 32 & 93 & 125 & $26 \%$ & $74 \%$ & $19 \%$ & $81 \%$ \\
\hline 731C-22R-1W & 29.3 & 38 & 91 & 129 & $29 \%$ & $71 \%$ & $23 \%$ & $77 \%$ \\
\hline
\end{tabular}

*Zircon ages $<200 \mathrm{Ma}$ are grouped into EAP (Eurasian plate) and $>200 \mathrm{Ma}$ are grouped into Himalaya.

${ }^{\dagger}$ Estimation of bulk budget is based on zircon fertilities of the EAP and Himalaya (Liang et al., 2019, Table DR7) 


\section{Table DR7}

Estimations of zircon fertilities of EAP and Himalaya based on heavy mineral analysis of detrital samples from local rivers (Liang et al., 2019).

\begin{tabular}{cccc}
\hline River name & Tectonic units & Sample name & Zircon Fertilities \\
\hline Hushe & Karakoram & $\mathrm{S} 1749$ & $1.6 \%$ \\
Braldu & Karakoram & $\mathrm{S} 1748$ & $0.9 \%$ \\
Hunza & Karakoram & $\mathrm{S} 1437$ & $0.5 \%$ \\
Hispar & Karakoram & $\mathrm{S} 1438$ & $2.2 \%$ \\
Stagmo & Ladakh & $\mathrm{S} 4426$ & $0.4 \%$ \\
Domkar & Ladakh & $\mathrm{S} 4430$ & $2.4 \%$ \\
Kandia & Kohistan & $\mathrm{S} 1439$ & $0.0 \%$ \\
Swat & Kohistan & $\mathrm{S} 1440$ & $0.2 \%$ \\
\hline Zanskar & EAP & $\mathrm{S} 4419$ & $\mathbf{1 . 0 \%}$ \\
Nandihar & Himalaya & $\mathrm{S} 1426$ & $0.9 \%$ \\
\hline & Himalaya & & $0.6 \%$ \\
\hline
\end{tabular}




\section{Table DR8}

The lag time and cooling rate calculated from apatite fission track ages of ODP 722 and 731

\begin{tabular}{cccccccc}
\hline Sample name & $\mathrm{n}$ & $\begin{array}{c}\text { Depositional } \\
\text { Age (Ma) }\end{array}$ & $\pm 2 \sigma^{*}$ & $\begin{array}{c}\text { Youngest } \\
\text { cooling peak } \\
\text { age (Ma) }{ }^{\dagger}\end{array}$ & $\pm 2 \sigma$ & $\begin{array}{c}\text { Lag time } \\
(\mathrm{m} . \mathrm{y} .)^{*}\end{array}$ & $\begin{array}{c}\text { Cooling rate } \\
\left({ }^{\circ} \mathrm{C} / \mathrm{m} . \mathrm{y} .\right)^{\S}\end{array}$ \\
\hline 722B-50X-1W & 93 & 15.8 & 1.4 & 19.6 & 1.5 & 3.8 & 28.9 \\
731B-4X-1W & 80 & 18.4 & 0.2 & 21.4 & 1.6 & 3.0 & 36.7 \\
731C-5W-4W & 70 & 22.0 & 1.5 & 25.9 & 2.0 & 3.9 & 28.2 \\
731C-8R-4W & 70 & 25.3 & 0.4 & 28.4 & 2.2 & 3.1 & 35.5 \\
731C-13W-4W & 85 & 27.0 & 0.4 & 31.0 & 2.3 & 4.0 & 27.5 \\
731C-22R-1W & 74 & 29.3 & 0.4 & 35.0 & 2.7 & 5.7 & 19.3 \\
\hline
\end{tabular}

"The error bars of the depositional ages follow the study on AFT dating of Bengal Fan deposits (Corrigan and Crowley, 1990) who define the uncertainties in the ages of the top and bottom of the $100 \mathrm{~m}$-interval which is a normal thickness for turbidite layer.

${ }^{\dagger}$ Youngest cooling peak ages are from Figure 4A. All samples were counted with a zeta calibration factor $\xi=343.0 \pm 23$ (Table DR12)

${ }^{*}$ Lag time (m.y.) = Youngest cooling peak age (Ma) - Depositional Age (Ma)

${ }^{\S}$ The cooling rate of the potential sources can be calculated by:

$$
\mathrm{E}=\frac{T_{c}-T_{s}}{t_{l}}
$$

Here, $\mathrm{E}$ is the cooling rate $\left({ }^{\circ} \mathrm{C} / \mathrm{m} . \mathrm{y}.\right) ; \mathrm{T}_{\mathrm{c}}$ is the closure temperature of $\operatorname{AFT}\left(110^{\circ} \mathrm{C}\right) ; \mathrm{T}_{\mathrm{s}}$ is the surface temperature $\left(0^{\circ} \mathrm{C}\right)$; and $\mathrm{t}_{\mathrm{l}}$ is the lag time (m.y.). 
Table DR9 (Supplemental Excel file).

Compiled zircon $\mathrm{U}-\mathrm{Pb}$ ages from sediment sources in the Indus River drainage basin.

Table DR10 (Supplemental Excel file).

Compiled Nd-Sr isotopic compositions from sediment sources in the Indus River drainage basin.

Table DR11 (Supplemental Excel file).

Raw data of zircon U-Pb ages of the samples from ODP Sites 722 and 731.

Table DR12 (Supplemental Excel file).

Raw data of apatite fission track ages of the samples from Sites ODP 722 and 731.

Table DR13 (Supplemental Excel file).

Compiled $\delta^{13} \mathrm{C}$ and $\delta^{18} \mathrm{O}$ records from pedogenic carbonates for deposits in South Asia 


\section{References from Data in Figures (1 and 2) and Tables (1 8)}

Clift, P.D., Giosan, L., Blusztajn, J., Campbell, I.H., Allen, C., Pringle, M., Tabrez, A.R., Danish, M., Rabbani, M.M., Alizai, A., Carter, A., and Lückge, A., 2008, Holocene erosion of the Lesser Himalaya triggered by intensified summer monsoon: Geology, v. 36, no. 1, p. 7982, doi: 10.1130/G24315A.1.

Clift, P.D., Zhou, P., Stockli, D.F., and Blusztajn, J., 2019, Regional Pliocene exhumation of the Lesser Himalaya in the Indus drainage: Solid Earth, v. 10, no. 3, p. 647-661, doi: 10.5194/se-10-647-2019.

Corrigan, J.D., and Crowley, K.D., 1990, Fission-Track Analysis of Detrital Apatites from Sites 717 and 718, Leg 116, Central Indian Ocean: Proceedings of the Ocean Drilling Program, Scientific Results, v. 116, p. 75-92.

Li, Y., Clift, P.D., and O'Sullivan, P., 2018, Millennial and centennial variations in zircon U-Pb ages in the quaternary indus submarine canyon: Basin Research, v. 31, no. 1, p. 155-170, doi: $10.1111 /$ bre.12313.

Liang, W., Garzanti, E., Andò, S., Gentile, P., and Resentini, A., 2019, Multimineral Fingerprinting of Transhimalayan and Himalayan Sources of Indus-Derived Thal Desert Sand (Central Pakistan): Minerals, v. 9, no. 8, p. 457.

Prell, W.L., and Niitsuma, N., 1989, Proceedings of the Ocean Drilling Program, Initial Reports, 117: Ocean Drilling Program, College Station, TX. 